\title{
Internalizing character education through Javanese traditional dance to realize child-friendly school
}

\author{
Siti Supeni ${ }^{1}$, Setyasih Harini ${ }^{2}$ \\ ${ }^{1}$ Pancasila and Civic Education Study Program, Universitas Slamet Riyadi, Surakarta, Indonesia \\ ${ }^{2}$ International Relations Study Program, Universitas Slamet Riyadi, Surakarta, Indonesia
}

\section{ABSTRACT}

The aims of the research are to (1) identify character education in various Javanese traditional dance, (2) to analyze the needs, output, problems, and learning objectives of child-friendly schools (CFS) in implementing character education based on regional dance, and (3) to identify types of Javanese traditional dance values. The methods of collecting the data used literary studies, interviews, surveys, observations, and documentation. In analyzing the data, the researchers employed Research \& Development model. Model of regional cultural development based on character education is supported through a psychological, educative, and socio-cultural approach, with qualitative descriptive analysis implemented in 2020. The research findings show that (1) identification character education in various Javanese traditional dance, (2) the needs, output, problems, and learning objectives of childfriendly schools (CFS) in implementing character education based on regional dance, and (3) types of Javanese traditional dance values. The implication of the research is the implementation of character education for elementary school students.
Article History:

Submitted : :01-02-2021

Revised : :03-03-2021

Accepted : 04-03-2021

Keywords:

Javanese Traditional Dance, Character

Education, Child-Friendly School

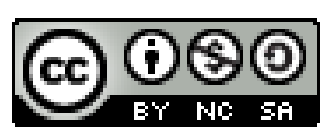

Cite in APA ${ }^{\text {th }}$ :

Supeni, S., \& Harini, S. (2021). Internalizing character education through javanese traditional dance to realize child-friendly school. Jurnal Civics: Media Kajian Kewarganegaraan, 18(1), 61-69.

https://doi.org/10.21831/JC.V18I1.38452

\section{Introduction}

Indonesia has many traditional dances showing that it respects its own culture, preserves as local heritage, and adopts it to educate society. Seblang dance is a traditional dance from Banyuwangi, Indonesia, promoting the community's welfare, preserving the land fertile, and convincing the successful next crop (Wessing, 1999). Sahita performance art has lessons to convey difficulty in daily life and to state critics in humorous styles. Its performance is traditional art completed with contemporary taste (Ardhiani, 2017). Describing how trance in Jathilan traditional dance is comprehended and performed according to the availability of literature, the 1st hand account of practitioners, many observed and documented performances, is considered in the context of Javanese beliefs its implementation (Rapoport, 2018)

There are many studies and articles to foster, preserve, and discuss traditional dances. Irianto (2016) conducted a study to describe the adapted strategy to keep and foster Jathilan Javanese traditional dance because it is viewed from the cultural identity that it has social and specific ritual roles. Arjo (1989) discussed the role of woman dancer in Sunda, West Java, Indonesia, in which she presents the woman's role from 1891 up to the present, that is Ronggeng dance. Christensen (2013) conducted a study to describe his argument about Jathilan dance in Yogyakarta. Saputra et al., (2019) carried out research to study the reproduction of creative cultural tourism in Soeryo Soemirat Mangkunegaran dance studio and the reproduction of the 
tourism in Soerya Soemirat studio, a 24 hours dancing performance. Dewi (2018) conducted research to express Panji tradition (Jaranan dance and Wayang Timplong) in an attempt to reveal the movement of the dance that it has a function as entertainment, not ceremony anymore. However, Wayang Timplong still has a function in the ceremony.

The innovation of traditional dances plays a significant role in preserving the dance and developing it to get interested in studying. Sawitri et al., (2016) carried out a study to express innovation of Bedhaya Angon-Angin, Bedhaya Silikon (uniform, music, properties) by artists out of the sacred Bedaya Javanese dance for market purpose. Slamet (2019) studied to provide knowledge and comprehension for the broader community about Jaranan Temanggungan dance pattern choreography for further development and to create new dance patterns forming the dance. Furthermore, Wisang (2019) studied Jaranan Turangga Yakso dance's co-modification because of tourism growth in Trenggalek, Indonesia. Also, dance as Javanese cultural art has the potency to develop character education in Surakarta, Denpasar, and West Jakarta to realize childfriendly city (Supeni et al., 2019).

Adopting local dance as a part of educational materials either inside or outside school perpetuates local culture and educates learners with their past culture having positive lessons. Reog values (for example, social and religion) in vocational high school are implemented in students' Reog performances (Ambarwangi, 2014). Maena traditional dance from Nias Island, usually for wedding and welcoming ceremonies and educational disasters, collaborated to educate society about the disaster (Shoji et al., 2020). Giyartini (2018) studied to form children's educational tourism model by redesigning creative dance packaging based on traditional games without leaving the values and enhancing children's intelligence and creativity. The formulation of Tuping dance in high school involves objective, material, method, model, media, and evaluation have been done (Marsim et al., 2019). Malarsih (2016) conducted a study to realize dance media as educational tools in the school curriculum. The result of the dance has fruitfully driven the students to become more active and creative. Rosmiati (2018) studied how the teaching strategies foster the nationalist's character by using songs and traditional games. One of the results is that national dancing dances are done as extracurricular activities.

The objectives of the research are to (1) identify character education in various Javanese traditional dance, (2) to analyze the needs, output, problems, and learning objectives of childfriendly schools (CFS) in implementing character education based on regional dance, and (3) to identify types of Javanese traditional dance values. The research's significance is to convey Javanese traditional dance values; therefore, teachers can adopt the values in their teaching, and students can employ the values in their activities.

\section{Method}

The goals of the research are to (1) identify character education in various Javanese traditional dance, (2) analyze the needs, output, problems, and learning objectives of child-friendly schools (CFS) in implementing character education based on regional dance, (3) identify types of Javanese traditional dance values. Data collection techniques in this study include interviews with persons related to the research object, recording data on various aspects of the regional dance character development model based on regional dance to support child-friendly schools in Surakarta, Indonesia. Study and review the literature that can provide information supporting this research and documenting through photoshoots of data such as regional dance activities carried out by children in Surakarta. The analysis in this study emphasizes the implementation of using a cultural approach. Interaction analysis is carried out to analyze qualitative data from empirical 
data collection results to obtain accurate results from classification by identification and identification.

\section{Result and Discussion}

\section{The Output of Joining "Kembang Joyo Art and Dance Gallery" and Problems Faced by the Gallery}

The author interviewed Mr. AB as owner and dance trainer of Kembang Joyo art and dance houses about the output of joining his house, as follows: There is four output. They can perform a dance outside the studio, at the invitation of the Institution who invited them, at the University of Slamet Riyadi Surakarta at the anniversary event, and graduation activities; able to dance in Karanganyar Regency as a performance for domestic/foreign tourists; able to perform arts at the celebration of the Republic of Indonesia's Independence day every year, to entertain the people in his village (Art Studio); and to perform arts routine every forty days (selapanan) on Saturday Pahing, in commemorating the day of Java the establishment of the "Joyo Flower Art Studio." Besides, Mr. AB get various problems in training and managing a dance. Mr. AB find limitations of inadequate facilities (practice room, gamelan music instruments); Not being able to run optimally because of a limited number of trainees, trainers, and limited funds; and the general availability of dancers' costumes that must be worn when the dance stage is performed has received 200 costumes from the Minister of Education and Culture

Mr. AB design some output that his students have to achieve. Being able to perform outside the gallery is one of the outputs to show the gallery's existence, especially students (dancers). It is also a medium to practice the dance's progress; therefore, he can get further action to face the progress, for example, giving additional treatment of dance to solve the problems in a particular movement. Dance viewers can also enjoy the dance from the movement and philosophical meaning behind the dance as entertainment and lesson for them. Being able to dance at the university level, for example, graduation or institution anniversary is pride that means that students get trust from society about the dance skill. Performing in the Indonesia independence celebration is also a target of him and his students to show local wisdom that should be preserved and show that the local wisdom (dance) still exists and has to be kept and preserved by all.

Besides, Mr. AB get problems in preserving the art gallery. Inadequate facilities to support dancing practice must not happen (practice room, gamelan music instruments) because tourists' number is a lot. It is exciting to entertain tourists who can support the Institution's finance because of insufficient financial support to facilitate trainers and trainees' activities; therefore, he needs to think to find various solutions. An inadequate number of trainees and trainers who can practice dancing need to be improved. Having 200 costumes needs to be preserved by practicing regularly.

\section{The Ways to Attract Students Interest and Work Plan to Develop the Art Gallery}

The author also asked Mr. AB to talk about his ways to attract students' interest and to develop the houses, in the following: I have some solutions to attract students' interest. Performing arts once a month (Saturday Pahing) to motivate to practice diligently, an explanation of the meaning of "dance" is done in building discipline character, being social, communicating politely with the trainer teacher and with his fellow friends. Social media's availability through the "Joyo Flower Art Studio," both from students/children, parents, the Government, and the community who also enjoy it performing arts performances from "Joyo Flower Art Studio." Then, they have many plans to foster the art studio. They collaborate with ISI Surakarta in providing professional help, trainer's collaboration with art lecturers from UNISRI Surakarta; providing adequate facilities, and making a simple stage renovation for dance performances, and mediating with other art galleries to collaborate in making art as a performance for tourist visitors. 
Mr. AB has some ideas to excite students' interest in dance practice. His schedule to practice dance once a month is very beneficial to train his students' dancing persistently. The activity is not merely to train dancing, but also to give a theoretical theory about the dance's philosophy being practiced understanding the essence and build communication between students and him and create social character during dancing. Social media use that contains performance from students/children, parents, the government, and the community is adequate to encourage students to practice preserving the dance. The media also promotes a variety of dances so that students can choose what kinds of dance they would like to practice based on their interests.

Mr. AB has many plans to develop his art studio. He collaborates with some related institutions, for example, with institut Seni Indonesia Surakarta to train his students and elementary school teachers who provide the lecturers to join trainers. He provides standard facilities for both dancing practice (for example, uniform) and buildings to facilitate (for example, restroom and stage for dance performance). Collaborating with other art galleries to design art programs to give tourists service is to strengthen the gallery's existence and provide cooperation in sharing ideas and experience in giving service to the tourists.

\section{Kinds of Javanese Traditional Dance Values}

The meaning of dance moves in character education's internalization based on regional cultural dance (Java). The meaning of motion has been the subject of thought of dance experts since ancient times. Even in India, it was written systematically more than 2000 years ago. Regarding the new character of dance thought by Western choreographers in the twentieth century (Soedarsono, 1972), the character of motion can be presented from the human body. This character of motion varies depending on which part of the human body it expresses. The upper part is the part that has an intellectual and spiritual character located on the chest up. Intellectual or spiritual expressions will be more successful if centered at the top. A feeling full of feelings lies in the middle, i.e., between the shoulder and the waist. This middle part has a feeling full of feelings. Emotions of dancers can be poured through this middle part, while the lower part is located between the waist and the floor. The lower part is a vital part full of life force (Soedarsono, 1972). Let's look further at the lines of motion. Dance movements can be broadly divided into two parts, namely symmetrical motion, and asymmetrical motion at appendix.

Table 1

The Values behind Javanese Local Dance

\begin{tabular}{|c|c|c|c|}
\hline No & Local Dance & Description & Character Education Values \\
\hline 1. & $\begin{array}{l}\text { Bedhaya } \\
\text { Ketawang }\end{array}$ & $\begin{array}{l}\text { Bedhaya Ketawang consists of the words } \\
\text { Bedhaya and Ketawang. Bedhaya means } \\
\text { female dancer in the palace. Ketawang } \\
\text { comes from the word 'Tawang', which } \\
\text { means star in the sky. This dance is very } \\
\text { thick with Javanese culture and is } \\
\text { considered sacred. }\end{array}$ & $\begin{array}{l}\text { 1. Obedience and faithfulness to } \\
\text { the King/leader. } \\
\text { 2. Develop a sense of love } \\
\text { towards others. } \\
\text { 3. Teaching the next generation } \\
\text { who remain faithful to the art } \\
\text { of regional dance is a culture } \\
\text { that will continue to be } \\
\text { preserved }\end{array}$ \\
\hline 2. & Serimpi & $\begin{array}{l}\text { Serimpi dance had existed since Prabu } \\
\text { Amiluhur when admission to Kraton } \\
\text { Kingdom received attention. The dance } \\
\text { that } 4 \text { daughters extracted each has its } \\
\text { name: water, fire, wind and earth or land, }\end{array}$ & $\begin{array}{l}\text { 1. Teaching about loyalty to the } \\
\text { environment } \\
\text { 2. Glorifying the Divine (Nilai2 } \\
\text { deity that creates nature; the } \\
\text { direction of wind, fire, earth). }\end{array}$ \\
\hline
\end{tabular}




No Local Dance
$\begin{aligned} & \text { which in addition to symbolizing man's } \\ & \text { occurrence, also symbolizes the four } \\ & \text { corners of the wind. The name of the role } \\ & \text { is Batak, Gulu, Dhada and Buncit. The } \\ & \text { composition of the quadrangle symbolizes } \\ & \text { the Pendopo pole. }\end{aligned}$

3. Gambyong

Derived from the Glondrong dance, which Nyi Mas Ajeng Gambyong extracted. The tower is very beautiful, plus the beauty and the sound capital is good. Finally, Nyi Mas was called by the Royal Palace of Surakarta to dance in the castle while giving lessons to the sons/l of the king. By the dance palace, it was transformed into Gambyong dance. The uniqueness of this dance lies in the dancers' movement with the rhythm of the gending and kendang played.

4. Beksan Wireng It comes from the words Wira (officer) and 'Aeng', The superior soldier, the 'Aeng', the 'linuwih'. This dance was created during Prabu Amiluhur in order that his sons were agile in the fight by using weapons of war. So, this dance depicts the agility in the exercise of war with the use of war tools.

5. Bambangan Cakil

\section{Bondan}

It is a dance that contains the value of high philosophy where wickedness, pride, arrogance and so on is meaningless because it will be crushed by goodness. This dance tells the war between the knights against the giants. The Knight is a character that is subtle and gentle, while the giant depicts a rough and brings figure.

This dance depicts the affection of a mother towards her child. Toy dolls, umbrellas, jars, and other properties are the hallmarks of dances that were once required in every village in Solo. The dance of Bondan Cindogo and Mardisiwi is a joyful dance, expressing compassion for his newborn son.
1. Teaches respect to guests.

2. Welcome and Offerings

3. Bring softness, smiles and humility to guest

1. The attitude of courage, prowess, and the courage of the soldiers.

2. Instilling into the child a warrior soul and heroism.

3. Assertive and authoritative attitude.

1. Show the child attitude and behavior good, dare to be true, from the character of Bambangan (Arjuna)

2. Show the child the attitude and evil behavior of the Cakil people.

3. Dare to fight Keangkara Murkaan/evil nature and arrogance (Giant Cakil)

4. Victory on the honest, strong, brave, and true party.

1. The attitude of affection and joy to the little boy (Baby).

2. Having a sense of responsibility to the younger brother makes sense of pleasure with the tote bags as an expression of compassion saying. 


\begin{tabular}{|c|c|c|c|}
\hline No & Local Dance & Description & Character Education Values \\
\hline & Topeng & $\begin{array}{l}\text { This dance is derived from wayang wong } \\
\text { or drama. Topeng Dance has experienced } \\
\text { success in the Majapahit era, her mask } \\
\text { was made of polished wood and } \\
\text { disungging according to the role of } \\
\text { character/roles taken from wayang } \\
\text { gedhog, menak panji. This dance is } \\
\text { growing rapidly since Islam entered mainly } \\
\text { by Sunan Kalijaga, which uses it as the } \\
\text { spreading of religion. }\end{array}$ & $\begin{array}{l}\text { Closing the face with the intent of } \\
\text { not showing arrogance, make } \\
\text { sense of confidence }\end{array}$ \\
\hline
\end{tabular}

Source: Research data, 2020.

Several Javanese traditional games studied in this research contain educational values. It is in line with Jazuli (2015), who studied and found cultural value systems growing and fostering Prajuritan dance of Semarang regency as one of his research findings. It is also in line with Setyaningrum et al., (2018), who conducted a study to determine the aesthetic values in the form, the content, and the performance of Gandaria dance in Rembang regency, Central Java, Indonesia. One of their results is that the dance's content contains an idea, atmosphere, and message that contain values of togetherness, association, and morality.

This research also shows how to increase learners' interest in dancing in which they practice dancing at the weekend. It is in line with Rosmiati (2018), who studied how the teaching strategies in fostering the nationalist's character by using songs and traditional dance, and one of the results is that national dancing dances are done out of school's time. Besides, empowering learners to repackage traditional dance helps appear their creativity, intelligence, active and creativity. It is in line with Giyartini (2018) who involve students in redesigning creative dance packaging based on traditional game without leaving the values and enhancing children's intelligence and creativity.

Students' role in this research is practicing dancing inside and outside of the dancing studio. Inside means dancing in the studio to practice dancing and its lessons. Outside means that they fulfill the invitation of dancing outside of the studio, dancing in Indonesia's Independence Day at the campus. It is in line with. Dewi (2018) who conducted research to express panji tradition (Jaranan dance and Wayang Timplong) in performing arts in East Java and attempt to reveal the dance movement that it has a function as entertainment, not ceremony anymore, although Wayang Timplong still has a function in the ceremony.

\section{Conclusion}

Character education in Javanese traditional games can be found in its movement, its implementation in a community, and collaboration with institutions. By identifying character education in various Javanese traditional dance, analyzing the needs, output, problems, and learning objectives of child-friendly schools (CFS) in implementing character education based on regional dance, (3) identifying types of Javanese traditional dance values, students, and dance trainers can get character education values to be taught to students to strengthen their character.

\section{Acknowledgment}

The researchers convey great thanks to the Rector of Universitas Slamet Riyadi for the chance given to them for carrying out the present study. They are grateful to the Dean of Teacher Training and Education Faculty for her support in this study. They state thank you to their colleague, Mrs. Harini, and Mr. Luqman Al Hakim, for their suggestion in writing this present article. Finally, they 
express their gratitude to all colleagues and students of Universitas Slamet Riyadi for their motivation and support in writing the article.

\section{References}

Ambarwangi, S. (2014). Reog as means of students' appreciation and creation in arts and culture based on the local wisdom. Harmonia: Journal of Arts Research and Education, 14(1), 3745. https://doi.org/10.15294/harmonia.v14i1.2789

Ardhiani, Y. D. (2017). Sahita's performance, satire of the life of Javanese women. International Journal of Creative and Arts Studies, 3(2), 63. https://doi.org/10.24821/ijcas.v3i2.1846

Arjo, I. D. (1989). Women's dance among the Sundanese of West Java, Indonesia. Asian Theatre Journal, 6(2), 168. https://doi.org/10.2307/1124458

Christensen, P. (2013). Modernity and spirit possession in Java - horse dance as a threatened space of interpretation. In DORISEA Working Paper (2, Issue 2). https://doi.org/10.13140/RG.2.2.14834.50885

Dewi, T. K. S. (2018). Panji tradition in the jaranan jor and wayang timplong performance arts in East Java. ISLLAC : Journal of Intensive Studies on Language, Literature, Art, and Culture, 2(2), 13-20. https://doi.org/10.17977/um006v2i22018p013

Giyartini, R. (2018). Development of child education tourism through creative dance in West Javabased traditional games. Proceedings of the 5th International Conference on Community Development (AMCA 2018), 231(5th), 91-93. https://doi.org/10.2991/amca-18.2018.26

Irianto, A. M. (2016). The development of Jathilan performance as an adaptive strategy used by Javanese farmers. Harmonia: Journal of Arts Research and Education, 16(1), 38-48. https://doi.org/10.15294/harmonia.v16i1.5213

Jazuli, M. (2015). Aesthetics of prajuritan dance in Semarang regency. Harmonia: Journal of Arts Research and Education, 15(1), 16. https://doi.org/10.15294/harmonia.v15i1.3692

Malarsih, M. (2016). The tryout of dance teaching media in public school in the context of appreciation and creation learning. Harmonia: Journal of Arts Research and Education, 16(1), 95. https://doi.org/10.15294/harmonia.v16i1.4561

Marsim, A. N., Mulyanto, \& Sudiyanto. (2019). Tuping dance learning at SMA Negeri 2 Kalianda South Lampung. International Conference on Arts Language and Culture (ICALC 2019), 421(Icalc 2019), 15-20. https://doi.org/10.2991/assehr.k.200323.003

Rapoport, E. (2018). Jathilan horse dance: Spirit possession beliefs and practices in the presentday Java. IKAT: The Indonesian Journal of Southeast Asian Studies, 2(1), 1. https://doi.org/10.22146/ikat.v2i1.37389

Rosmiati, S. H. (2018). Developing the nationalism character of young learners by using songs and traditional dances of Indonesia. International Conference on the Roles of Parents in Shaping Children's Characters (ICECED), 287-292.

Saputra, R. G. C., Supriyadi, \& Demartoto, A. (2019). Reproduction of Javanese dance in Soeryo Soemirat. International Journal of Education and Social Science Research, 2(2), 97-115. https://ijessr.com/link1.php?id=128

Sawitri, Sudardi, B., Abdullah, W., \& Chaya, N. (2016). Innovations in Bedhaya dance in the age of globalization. Journal of Education and Social Sciences, 5(2), 318-323. 
Setyaningrum, H., Asma, M. U., \& Indriyani, P. D. (2018). Aesthetic review of Gandaria dance show in Rembang regency. The 2nd International Conference on Arts and Culture (ICONARC 2018), 276, 39-43. https://doi.org/10.2991/iconarc-18.2019.64

Shoji, M., Takafuji, Y., \& Harada, T. (2020). Behavioral impact of disaster education: Evidence from a dance-based program in Indonesia. International Journal of Disaster Risk Reduction, 45(August 2019), 1-13. https://doi.org/10.1016/j.ijdrr.2020.101489

Slamet. (2019). The development of Jaranan Temanggungan as Indonesian intangible heritage. Arts and Design Studies, 77, 45-54. https://doi.org/10.7176/ADS/77-06

Soedarsono, R. (1972). Djawa dan Bali: Dua pusat perkembangan seni drama tradisional di indonesia. Gajah Mada University Press.

Supeni, S., Nurati, D. E., Sufa, F. F., \& Jumintono. (2019). Character education development model based on regional culture. Journal of Advanced Research in Dynamical and Control Systems, 11(5 Special Issue), 673-683. https://www.jardcs.org/abstract.php?id=1193\#

Wessing, R. (1999). A dance of life; The Seblang of Banyuwangi, Indonesia. Bijdragen Tot de Taal-, Land-En Volkenkunde / Journal of the Humanities and Social Sciences of Southeast Asia, 155(4), 644-682. https://doi.org/10.1163/22134379-90003865

Wisang, A. M. (2019). Cultural co-modification of Jaranan Turangga Yakso dance in Jaranan Festival in Trenggalek region. Journal of Advances in Social Science and Humanities, 5(1), 555-561. https://doi.org/10.15520/jassh51394 


\section{Appendix:}

Symmetrical motion and asymmetrical motion in traditional dance:

1. Symmetrical lines have a simple character, sturdy, calm but boring if used too often. (Characters that are simple, sturdy, calm)

2. Asymmetrical lines have a less sturdy character but are dynamic and attractive. With the motion lines with differences in character, then a choreographer so that his work remains interesting, it is recommended to use more asymmetrical lines. (dynamic and interesting characters).

3. The motion lines can also be divided into two types: cross lines or will meet and separate lines or direction. The motion character on the cross lines is full of energy and vitality, while the separate lines have a smooth and soft character.

4. Every move expressed by a dancer will give a certain impression to the audience. (make you feel happy/happy because you can enjoy the art of beauty from dance movements).

5. The meaning of motion integrated into a motion; For example, if a dancer would describe crying, he would use meaningful motion by covering his face and shrinking his body. (making sense of compassion, empathy for the meaning of the story being danced will hone the sharpness of the soul (if taste, if the soul). Thus, the dancer will express the movement of crying or sadness when combining the meaning of the hands that cover the face with the body and reduced or contracted limbs.

6. Dance movements can be distinguished based on the volume of motion, which can be divided into three, namely large, medium and small volumes. Large or open volumes have a male nature, small or closed volumes have a feminine character, and medium volumes give the impression of subtle maleness and femininity.

7. Motion is more careful about motion patterns, each of which has its character. Flat-patterned movements have character/character; open, honest, but also shallow/simple character.

8. Vertically patterned motion has an egocentric character and is perfect for expressing surrender.

9. Horizontal-patterned movements have a feeling of wanting to leave.

10. Cross-patterned motion gives a strong impression but also a confused impression.

11. Pure patterned motion, not a single part of the crossing body has a calm and open character.

12. Sweet, curved patterns of motion.

13. Motion that is patterned straight or elbows gives a strong impression. 